\title{
Hypoxaemia and hypotension after intravenous codeine phosphate
}

This report describes a case of accidental intravenous administration of codeine phosphate $\left(1 \mathrm{mg} \cdot \mathrm{kg}^{-l}\right)$ to a previously healthy five-year-old boy, who was undergoing strabismus surgery. Hypoxaemia ( $\mathrm{SpO}_{2} 85 \%$ with $\mathrm{FlO}_{2}$ of 1) and hypotension (systolic BP $65 \mathrm{~mm} \mathrm{Hg}$ ) resulted, which responded to resuscitation with lactated Ringers' $\left(20 \mathrm{ml} \cdot \mathrm{kg}^{-1}\right)$ and phenylephrine $\left(2 \mu \mathrm{g} \cdot \mathrm{kg}^{-1}\right)$. The degree of hypoxaemia observed in this case was severe, but was not associated with clinical evidence of bronchospasm. Possible mechanisms for this reaction might have included direct myocardial depression and histamine release. This case adds further support to the recommendation that codeine phosphate should never be administered intravenously.

Cette observation décrit linjection intraveineuse accidentelle de phosphate de codéine $\left(\mathrm{I} \mathrm{mg} \cdot \mathrm{kg}^{-1}\right)$ à un garçon de cinq ans jusque-là bien portant soumis à une correction chirurgicale de strabisme. Il est apparu une hypoxémie ( $\mathrm{SpO} \mathrm{O}_{2} 85 \%$ avec une $\left.\mathrm{FIO}_{2}=1,0\right)$ et une l'hypotension (PAS $65 \mathrm{mmHg}$ ) qui ont bien répondu à l'administration de lactate de Ringer (20 $\left.\mathrm{ml} \cdot \mathrm{kg}^{-1}\right)$ et de phényléphrine $\left(2 \mu \mathrm{g} \cdot \mathrm{kg}^{-1}\right)$. Dans le cas présent, le degré d'hypoxémie était grave mais n'était de toute évidence pas causé par un bronchospasme. Une dépression myocardique directe accompagnée dhistamino-libération pourrait constituer le mécanisme plausible de cette réaction. Cette observation endosse une fois plus la recommandation selon laquelle on ne doit jamais administrer de phosphate de codéine par la voie intraveineuse.

\section{Key words}

ANAESTHESIA: paediatric;

ANALGESICS: codeine phosphate;

COMPLICATIONS: hypoxaemia, hypotension.

From the Department of Anaesthesia, Alberta Children's Hospital, 1820 Richmond Road S.W., Calgary, Alberta, T2T 5 C7.

\footnotetext{
Address correspondence to: Dr. R.G. Cox.
}

Accepted for publication 12th August, 1994.
Codeine phosphate is an opioid agonist, active at the $\mu$ receptor site. This analgesic is popular in paediatric practice, as it provides reliable analgesia for mild to moderate pain, with a low incidence of troublesome side effects. Adverse reactions to iv codeine phosphate have been described previously in both adults ${ }^{1}$ and children. ${ }^{2}$ These reactions have included apnoea, hypotension and tachycardia, sometimes in association with a generalized erythematous rash. In view of such reactions, it has been recommended that codeine phosphate should be avoided by the $i v$ route. ${ }^{3,4}$ One common practice is to administer the drug by the im route prior to emergence from general anaesthesia. At the Alberta Children's Hospital, codeine phosphate (1-1.5 $\left.\mathrm{mg} \cdot \mathrm{kg}^{-1}\right)$ is frequently given im during minor surgery (e.g., strabismus repair, dental restorations, adenoidectomy). A case is described in which codeine phosphate, accidentally given $i v$ resulted in hypoxaemia and hypotension.

\section{Case report}

A five-year-old boy, $25.1 \mathrm{~kg}$, presented for a left lateral rectus muscle recession for correction of strabismus. The patient had received no oral solids on the day of surgery but had taken oral clear fluids four hours preoperatively. $\mathrm{He}$ was assessed as being generally healthy, apart from a history of mild asthma, which had led to two previous hospital admissions.

He had had one previous anaesthetic, also for stabismus surgery, and had been "croupy and wheezy" for two days postoperatively. He took inhaled sodium cromoglycate and was also receiving oral vitamin supplements. He was noted to have various environmental allergies. Preoperative physical examination was normal and he had no clinical evidence of bronchospasm. No premedication was administered. General anaesthesia was induced with halothane (maximum $3 \%$ inspired concentration), nitrous oxide and oxygen (33\%). Following induction of anaesthesia, venous access was established and atropine $0.2 \mathrm{mg}$, metoclopramide $2 \mathrm{mg}$ and lidocaine $20 \mathrm{mg}$ were given $i v$. Once an adequate depth of anaesthesia was obtained, the trachea was intubated orally and spontaneous respiration was allowed to continue. The in- 
spired halothane concentration was reduced to $2 \%$. Monitoring included ECG, $\mathrm{SpO}_{2}, \mathrm{ETCO}_{2}$ and $\mathrm{FIO}_{2}$. Surgery then commenced. It had been planned to administer codeine phosphate $25 \mathrm{mg}$ im but, in error, the drug was given by rapid $i v$ injection. Shortly thereafter, there was a decrease in arterial blood pressure and in $\mathrm{SpO}_{2}$ (Figure). The patient was immediately given $100 \%$ oxygen and the lungs were ventilated manually. The inspired halothane concentration was reduced to $0.25-0.5 \%$. Lactated Ringers' $\left(20 \mathrm{ml} \cdot \mathrm{kg}^{-1}\right)$ was infused rapidly. The patient appeared centrally flushed, but peripheral perfusion was poor and he had markedly delayed capillary refill. Auscultation of the lungs was normal and there was no clinical evidence of bronchospasm; lung compliance was felt to be normal. Despite these measures, systolic blood pressure remained at $65-70 \mathrm{mmHg}$ and the $\mathrm{SpO}_{2}$ at $85 \%$. Phenylephrine $\left(2 \mu \mathrm{g} \cdot \mathrm{kg}^{-1}\right) i v$ was given $15 \mathrm{~min}$ after the injection of codeine and the arterial blood pressure and $\mathrm{SpO}_{2}$ slowly improved. An arterial blood gas sample, taken $20 \mathrm{~min}$ after the codeine phosphate, indicated a $\mathrm{pH}$ of $7.28, \mathrm{PaCO}_{2}$ of $42 \mathrm{mmHg}, \mathrm{PaO}_{2}$ of $76 \mathrm{mmHg}$ and a base excess of $-7 \mathrm{mEq} \cdot \mathrm{L}^{-1}$. Thirty-five minutes after codeine phosphate administration, the arterial blood pressure had increased to $108 / 68 \mathrm{mmHg}$ and the $\mathrm{SpO}_{2}$ was $96 \%$ with an $\mathrm{FIO}_{2}$ of 1 . Surgery had been completed expeditely and the patient emerged from anaesthesia and the trachea was extubated when he was awake. He was monitored in the recovery room for one hour and his vital signs remained stable. He was weaned from oxygen and his $\mathrm{SpO}_{2}$ was $95 \%$ in room air one hour following extubation. When assessed three hours later he still had normal vital signs and had no evidence of a rash or of bronchospasm. Thereafter he made an uneventful recovery.

\section{Discussion}

In our institution, codeine phosphate is supplied in a 1 $\mathrm{ml}$ vial $\left(30 \mathrm{mg} \cdot \mathrm{ml}^{-1}\right)$, and is labeled as being for subcutaneous or intramuscular use (Abbott). The drug is formulated in a single-use vial, and the only additive is sodium metabisulfite $0.1 \%$, as a stabilizer. Sodium metabisulfite has been implicated in some hypersensitivity reactions; these have been reported most frequently after ingestion of restaurant foods treated with sulfites. ${ }^{5}$ In asthmatics, inhaled sulfites may cause adverse reactions. Sodium metabisulfite, however, is added to many drugs that are commonly administered $i v$ without adverse effect (e.g., dopamine, morphine sulphate, d-tubocurarine). It is not likely, therefore, that sodium metabisulfite is responsible for the reactions that have been reported with codeine phosphate $i v$.

The most likely cause of hypotension following codeine phosphate $i v$ is histamine release, although direct myocar-

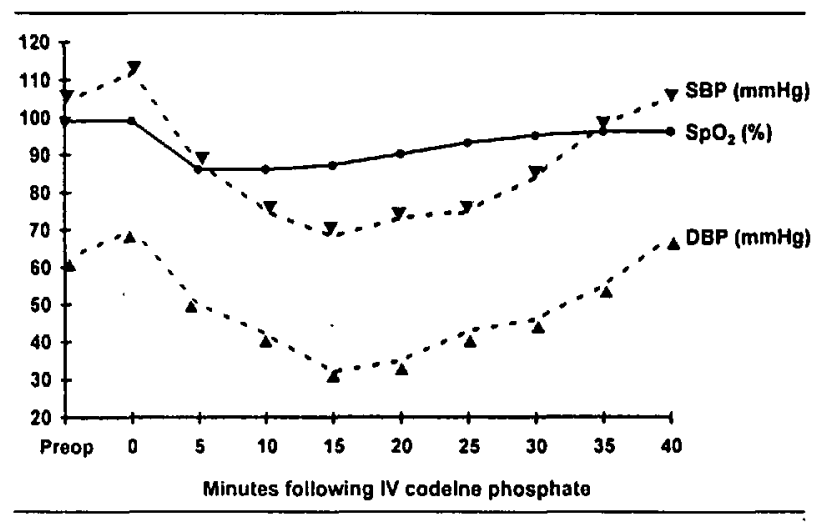

FIGURE Arterial blood pressure and oxygen saturation following administration of intravenous codeine phosphate.

dial depression is another possibility. In equi-analgesic doses to morphine, codeine has greater histamine releasing activity. ${ }^{6}$ It is probably the speed of injection ${ }^{1,2}$ that leads to severe clinical reactions, such as the one described. The route of administration is crucial, as similar reports have not been described after codeine phosphate im. The three children reported by Shanahan ${ }^{1}$ had all received codeine phosphate im without adverse effects, but reacted when the drug was given $i v$.

The degree of hypoxaemia noted in our patient was marked, despite there being no evidence of bronchospasm. It is speculated that this may have been related to decreased pulmonary perfusion from hypotension and myocardial depression. The patient's poor peripheral perfusion and mild metabolic acidosis would be compatible with decreased cardiac output. Previous similar reports have not commented on the $\mathrm{SpO}_{2}{ }^{1,2}$

The reaction presented was initially managed with positive-pressure ventilation with oxygen and rapid infusion of lactated Ringers' $i$. Halothane in low concentrations was continued, primarily as a bronchodilator, although there was no evidence of bronchospasm. It was noteworthy that the patient, who was not paralyzed, appeared adequately anaesthetized on $0.5 \%$ halothane; it is likely that the codeine reduced the MAC for halothane. The clinical response to crystalloid was poor indeed, the blood pressure continued to decrease for 15 min after the injection of codeine. Administration of phenylephrine at this time appeared to reverse the hypotension although the response was slow. Had the reaction been more severe, epinephrine $\dot{i}$ would have been required as in two of the three cases reported by Parke et al. ${ }^{1}$

Clinical anaesthetists are predominantly used to giving injected drugs by the $i v$ route. There is a real risk therefore that drugs intended for im use might be given $i v$. In any anaesthesia situation where drugs not intended for $\dot{i v}$ route are drawn up, these should be placed separately 
from the other iv drugs and should be labeled clearly. It is recommended, specifically, that codeine phosphate should never be given $i v$ and that meticulous aspiration testing be performed during im injection.

\section{References}

1 Parke TJ, Nandi PR, Bird KJ, Jewkes DA. Profound hypotension following intravenous codeine phosphate. Three case reports and some recommendations. Anaesthesia 1992; 47: 852-4.

2 Shanahan EC, Marshall AG, Garrett CPO. Adverse reactions to intravenous codeine phosphate in children. A report of three cases. Anaesthesia 1983; 38: 40-3.

3 Steward DJ. Manual of Pediatric Anesthesia, 3rd. Ed. New York: Churchill Livingstone 1990; 408.

4 Yaster $M$, Maxwell $L G$. Opioid agonists and antagonists. 'In: Schechter NL, Berde CB, Yaster M (Eds.). Pain in Infants, Children and Adolescents. Baltimore: Williams \& Wilkins 1993: 160.

5 Canadian Pharmaceutical Association. Compendium of Pharmaceuticals and Specialties 1994: B78.

6 Stoelting RK. Pharmacology and Physiology in Anesthetic Practice. Philadelphia: J.B. Lippincott 1987: 88. 